\title{
Perbedaan Rasio Kolesterol Total/ HDL Kelompok Kontrol dan Kelompok Diet Tinggi Minyak Sawit pada Tikus Wistar
}

\author{
Yelsa Yulanda Putri, Ellyza Nasrul, Susila Sastri
}

\begin{abstract}
Abstrak
Rasio kolesterol total/ HDL merupakan variabel lipoprotein terbaik dalam memprediksi risiko penyakit kardiovaskular. Peningkatan risiko penyakit kardiovaskular dapat disebabkan oleh tingginya kadar kolesterol serum. Minyak sawit mengandung 50\% asam lemak jenuh dan 50\% asam lemak tidak jenuh. Tujuan penelitian ini adalah mengetahui perbedaan rasio kolesterol total/ HDL antara kelompok kontrol dengan kelompok diet tinggi minyak sawit pada tikus. Penelitian ini adalah eksperimental dengan pendekatan post test only control group design. Sampel penelitian terdiri dari 10 ekor tikus Wistar jantan yang dibagi menjadi kelompok kontrol $(\mathrm{K})$ dan kelompok perlakuan (P). Diet tinggi minyak sawit (minyak sawit $42.5 \%$, 3ml/hari) diberikan pada kelompok $\mathrm{P}$ selama empat minggu. Analisis data menggunakan uji $t$ independent. Hasil penelitian menunjukkan terdapat perbedaan peningkatan yang tidak bermakna antara kelompok $P$ dan kelompok $K$ pada rerata kolesterol, yaitu 63.66 $\pm 9.9(P) 57.39 \pm 3.28(K)(p>0.05)$, rerata HDL 19.44 $\pm 3.99(P) 17.64 \pm 2.00(K)$ ( $p>0.05)$, dan rerata rasio kolesterol total/ HDL $3.26 \pm 0.24(P) 3.31 \pm 0.32(K)$ ( $p>0.05)$. Kesimpulan penelitian ini adalah kadar kolesterol total, HDL, dan rasio kolesterol total/ HDL pada kelompok kontrol dan kelompok diet tinggi minyak sawit tidak berbeda.
\end{abstract}

Kata kunci: diet tinggi minyak sawit, kolesterol, HDL, rasio kolesterol/ HDL

\begin{abstract}
The ratio of total cholesterol/ HDL is the lipoprotein variables best predict the risk of cardiovascular disease. The increased risk of cardiovascular disease can be caused by high levels of cholesterol exciting. Palm oil contains $50 \%$ saturated fatty acids and $50 \%$ unsaturated fatty acids. The purpose of this study was to know the differences ratio of total cholesterol/ HDL between the control group and high palm oil diet group in rats. This research was experimental with post-test only control group. The study sample consisted of 10 male Wistar rats were divided into control group $(K)$ and treated group $(P)$. High-palm oil diet (50\% palm oil, 3ml/day) was given to the group $P$ for four weeks. Analysis of data using independent $t$ test. The results showed there were no significant differences in improvement between groups $P$ and groups $K$ in mean cholesterol, $63.66 \pm 9.9(P) 57.39 \pm 3.28(K)$ in $(p>0.05)$, mean $H D L 19.44 \pm 3.99(P) 17.64 \pm 2.00(K)$ in ( $p>0.05$ ), and the mean ratio of total cholesterol/ HDL $3.26 \pm 0.24$ (P) $3.31 \pm 0.32(K)$ in ( $p>0.05$ ). The conclusion of this study is total cholesterol, HDL, and the ratio of total cholesterol/ HDL in the control group and the high palm oil diet group did not differ.
\end{abstract}

Keywords: high palm oil diet, cholesterol, HDL, ratio of cholesterol/HDL

Affiliasi penulis : Fakultas Kedokteran Universitas Andalas Korespondensi : Yelsa Yulanda Putri. email: yelsa08.putri@gmail.com, Telp: 085266923003

\section{PENDAHULUAN}

Rasio kolesterol total terhadap kolesterol High Density Lipoprotein (HDL) atau disebut juga Cardiac Risk Ratio merupakan angka perbandingan antara kadar kolesterol total dengan kadar kolesterol HDL. ${ }^{1}$ Menurut American Heart Association (AHA) bahwa dari tahun 1998 hingga 2008 rata-rata kematian akibat penyakit kardiovaskular sebesar $30,6 \%{ }^{2}$ World Health Organization (WHO) melaporkan pada tahun 2008 angka kematian penyakit kardiovaskular di Indonesia mencapai 30\% dan penyebab kematian nomor satu di Indonesia (WHO, 2011). ${ }^{3}$ Menurut Yankes DKK Padang penyakit jantung menempati peringkat nomor 4 sebagai penyebab kematian di kota Padang pada tahun 2011 yaitu 60 dari 454 kematian atau sekitar 13,2\%. 
Studi epidemiologi menyatakan bahwa peningkatan risiko penyakit kardiovaskular dapat disebabkan oleh tingginya kadar kolesterol serum. ${ }^{5}$ Asupan tinggi lemak (kolesterol) dan asupan rendah asam lemak tidak jenuh akan meningkatkan kadar kolesterol serum sehingga menjadi risiko berkembangnya plak aterosklerosis pada pembuluh darah. $^{5,6}$

Salah satu sumber asupan asam lemak adalah melalui konsumsi minyak. Menurut Survei Sosial Ekonomi Nasional (SUSENAS) dalam BPS 2011 rata-rata konsumsi minyak mulai tahun 1998 hingga 2010 meningkat yaitu dari 205,9 kalori per kapita sehari hingga 233,39 kalori per kapita sehari. ${ }^{7}$

Minyak sawit adalah lemak alami stabil yang mengandung 99\% asam lemak rantai panjang. Perbandingan komposisi asam lemak jenuh (Saturated Fatty Acid, SFA) dan asam lemak tidak jenuh (Unsaturated Fatty Acid, UFA) pada minyak sawit hampir sama, yaitu 50\% SFA dan 50\% UFA Pada minyak sawit SFA terdiri dari $44 \%$ asam palmitat dan $5 \%$ asam stearat, sedangkan UFA terdiri dari $40 \%$ asam lemak tak jenuh tunggal (Monounsaturated Fatty Acid, MUFA), yaitu asam oleat dan $10 \%$ asam lemak tak jenuh jamak (Polyunsaturated Fatty Acid, PUFA) berupa asam linoleat. ${ }^{8}$

Terdapat kontroversi mengenai pemberian diet tinggi minyak sawit terhadap kadar kolesterol total dan HDL. WHO di tahun 2003 menyatakan terdapat bukti yang meyakinkan bahwa konsumsi asam palmitat berkontribusi terhadap peningkatan risiko penyakit kardiovaskular. ${ }^{5}$ Hasil berbeda dari suatu penelitian pada dua perlakuan (diet tinggi asam palmitat dengan diet rendah asam palmitat) menunjukkan bahwa tidak ada hubungan antara sintesis kolesterol endogen dengan kandungan asam palmitat dalam makanan. ${ }^{9}$

Berdasarkan latar belakang maka penulis tertarik untuk membandingkan rasio kolesterol total/ HDL antara kelompok kontroldengan kelompok diet tinggi minyak sawit pada tikus wistar. Tujuan penelitian ini adalah mengetahui perbedaan rasio kolesterol total/ HDL antara kelompok kontrol dengan kelompok diet tinggi minyak sawit pada tikus. Tujuan khusus penelitian ini adalah mengetahui perbedaan kadar kolesterol total antara kelompok kontrol dengan kelompok diet tinggi minyak sawit pada tikus dan mengetahui perbedaan kadar HDL antara kelompok kontrol dengan kelompok diet tinggi minyak sawit pada tikus.

\section{METODE}

Jenis penelitian ini adalah penelitian eksperimental (true experiment designs) dengan rancangan post test only control group design dan menggunakan tikus sebagai hewan coba. Sampel penelitian terdiri dari 10 ekor tikus Wistar jantan yang dibagi menjadi kelompok kontrol (K) dan kelompok perlakuan $(\mathrm{P})$. Kelompok $\mathrm{P}$ diberi diet tinggi minyak sawit, sementara kelompok $\mathrm{K}$ diberi diet standar. Besar sampel ditentukan dengan rumus menurut Fraenkle and Wallen.

Kriteria inklusi adalah tikus jantan, sehat, berat badan tikus 180 - 250 gram, berumur \pm 2 bulan saat pemilihan sampel. Kriteria eksklusi adalah tikus mengalami penurunan berat badan.

Variabel bebas penelitian ini adalah diet tinggi minyak sawit. Diet tinggi minyak sawit yang digunakan adalah diet standar dengan tambahan 42.5\% minyak sawit ad libitum.

Variabel tergantung terdiri dari kadar kolesterol total, kadar HDL, dan rasio kolesterol total/ HDL. Pengukuran kadar kolesterol dan HDL dilakukan dengan cara Cholesterol Oxidase Peroxidase Amino Phenzon Phenol (CHOD PAP) Enzymatic Photometric Test dengan menggunakan spektrofotometer.

Penelitian dilakukan di laboratorium Farmakologi dan Fisiologi Fakultas Farmasi Universitas Andalas sebagai tempat pemeliharaan tikus dan pengambilan sampel.

Aklimatisasi terhadap hewan coba dilakukan selama 7 hari untuk membiasakan hewan pada kondisi percobaan dan diberi makanan standar dan minuman yang cukup. Setiap kelompok sampel diberikan makanan yang sama. Kelompok $\mathrm{P}$ kemudian diberi diet tinggi minyak sawit (diet standar dengan tambahan $42.5 \%$ minyak sawit) sebanyak $3 \mathrm{ml} /$ hari ad libitum. Sedangkan Kelompok K diberi diet standar ad libitum selama 4 minggu.

Setelah empat minggu perlakuan, semua hewan coba diukur kadar kolesterol total dan HDL. Sebelum pengambilan darah, tikus dianastesi dengan 
dietil eter. Pengambilan sampel darah diambil dari vena jugular darah tikus. Darah dipipet $2 \mathrm{ml}$ dengan menggunakan spuit, kemudian dimasukkan ke tabung mikrosentrifus. Darah disentrifugasi dengan kecepatan 3000-4000 rpm selama 15-20 menit dan didiamkan selama 15 menit untuk mendapatkan serum.

Pengukuran kadar kolesterol total dilakukan dengan cara serum sampel dan standar sebanyak 10 $\mu \mathrm{l}$ dimasukkan ke dalam tabung reaksi yang sudah disterilisasi dan ditambahkan reagen sebanyak $1000 \mu$ l. Sampel dan reagen dihomogenkan,kemudian diinkubasi selama 10 menit pada suhu $37^{\circ} \mathrm{C}$ atau selama 20 menit pada suhu $20-25^{\circ} \mathrm{C}$ dan dibaca absorbansinya pada panjang gelombang $500 \mathrm{~nm}$.

Pengukuran HDL dilakukan dengan terlebih dahulu melakukan presipitasi terhadap lipoprotein densitas rendah (LDL dan VLDL) dan kilomikron. Presipitasi dilakukan dengan penambahan asam fosfotungstat dan ion magnesium $\left(\mathrm{MgCl}_{2}\right)$. Setelah sentrifugasi, HDL dalam supernatant diukur menggunakan pereaksi kit yang sama dengan pengukuran kolesterol total (CHOD-PAP).

Data dianalisis secara statistik dengan program komputer. Pengujian dilakukan sesuai dengan distribusi data. Jika distribusi data normal dilakukan uji $\mathrm{t}$ independent dan jika distribusi data tidak normal dilakukan uji non parametrik seperti uji Mann-Whitney. Semua nilai yang didapatkan dari hasil penelitian disajikan dalam bentuk Mean (rata-rata) \pm SD (Standard Deviation).

\section{HASIL}

Hasil pengukuran kadar kolesterol tikus Wistar jantan pada kelompok kontrol $(\mathrm{K})$ yaitu rerata kadar kolesterol total adalah $57.39 \pm 3.28 \mathrm{mg} / \mathrm{dl}$, sedangkan pada kelompok perlakuan $(P)$ yaitu $63.66 \pm 9.91 \mathrm{mg} / \mathrm{dl}$.

Berdasarkan hasil uji normalitas Kormogorov dan Saphiro Wilk didapatkan distribusi data normal, yaitu $p>0.05$. Data tersebut kemudian dianalisis secara statistik dengan menggunakan $t$-test independent.
Tabel 1. Perbedaan Rerata Kadar Kolesterol Total Kelompok Kontrol dan Perlakuan

\begin{tabular}{llll}
\hline Kelompok & $\mathbf{n}$ & Kolesterol Total $(\mathbf{m g} / \mathbf{d l})$ & \multirow{2}{*}{$\mathbf{p}$} \\
\cline { 3 - 3 } & & Mean \pm SD & \\
\hline Kontrol & 5 & $57.39 \pm 3.28$ & 0.238 \\
Perlakuan & 5 & $63.66 \pm 9.91$ & \\
\hline
\end{tabular}

Pada analisis data dengan $t$ test independent menunjukkan $p=0.238$ ( $p>0.05)$, artinya tidak terdapat perbedaan yang bermakna antara kadar kolesterol total kelompok kontrol dengan kelompok perlakuan.

Hasil pengukuran kadar HDL tikus Wistar jantan pada kelompok kontrol yaitu rerata kadar HDL adalah $17.64 \pm 2.00 \mathrm{mg} / \mathrm{dl}$, sedangkan pada kelompok perlakuan adalah $19.44 \pm 3.99 \mathrm{mg} / \mathrm{dl}$.

Dari hasil uji normalitas Kormogorov dan Saphiro Wilk didapatkan distribusi data normal, yaitu $p>0.05$. Data tersebut kemudian dianalisis secara statistik dengan menggunakan $t$-test independent.

Tabel 2. Perbedaan Rerata Kadar HDL Kelompok Kontrol dan Perlakuan

\begin{tabular}{llcl}
\hline Kelompok & $\mathbf{n}$ & HDL $(\mathbf{m g} / \mathbf{d l})$ & $\mathbf{p}$ \\
\cline { 3 - 3 } & & Mean \pm SD & \\
\hline Kontrol & 5 & $17.64 \pm 2.00$ & 0.404 \\
Perlakuan & 5 & $19.44 \pm 3.99$ & \\
\hline
\end{tabular}

Hasil $t$-test independent didapatkan $\mathrm{p}=0.404$ ( $p>0.05)$ artinya tidak terdapat perbedaan yang bermakna antara kadar HDL kelompok kontrol dengan kelompok perlakuan.

Hasil penghitungan rasio kolesterol total/ HDL tikus Wistar jantan kelompok kontrol adalah 3.26 \pm 0.24 $\mathrm{mg} / \mathrm{dl}$, sedangkan pada kelompok perlakuan adalah $3.31 \pm 0.32 \mathrm{mg} / \mathrm{dl}$.

Tabel 3. Perbedaan Rerata Rasio Kolesterol Total/ HDL Kelompok Kontrol dan Perlakuan

\begin{tabular}{|c|c|c|c|}
\hline \multirow{3}{*}{ Kelompok } & \multicolumn{3}{|c|}{ Rasio Kolesterol } \\
\hline & \multirow[t]{2}{*}{$\mathbf{n}$} & Total/ HDL & \multirow[t]{2}{*}{$\mathbf{p}$} \\
\hline & & Mean \pm SD & \\
\hline Kontrol & 5 & $3.26 \pm 0.24$ & \multirow{2}{*}{0.802} \\
\hline Perlakuan & 5 & $3.31 \pm 0.32$ & \\
\hline
\end{tabular}


Berdasarkan t-test independent didapatkan $p=0.802 \quad(p>0.05)$ artinya tidak terdapat perbedaan yang signifikan atau bermakna antara rasio kolesterol total/HDL kelompok kontrol dengan kelompok perlakuan.

\section{PEMBAHASAN}

Berdasarkan analisis data penelitian ini menunjukkan bahwa rerata kadar kolesterol total kelompok perlakuan diet tinggi minyak sawit lebih tinggi daripada kelompok kontrol, namun tidak terdapat perbedaan yang bermakna antara 2 kelompok tersebut. Hasil yang didapatkan pada penelitian ini sejalan dengan penelitian yang dilakukan oleh French dkk bahwa kandungan asam palmitat yang tinggi dalam makanan tidak berpengaruh nyata terhadap kolesterol total serum. ${ }^{9}$ Jumlah sintesis kolesterol tidak berbeda pada dua perlakuan (diet tinggi asam palmitat dengan diet rendah asam palmitat). ${ }^{10}$ Hasil yang didapat pada penelitian ini berbeda dengan hasil penelitian Karaji-Bani yang menggunakan tikus wistar diberi diet minyak sawit $12 \%$ selama 60 hari menunjukkan terdapat perbedaan yang bermakna. ${ }^{11}$

Minyak sawit merupakan sumber asam palmitat (SFA) dan asam oleat (MUFA) dengan komposisi yang hampir sama. ${ }^{8}$ Kadar kolesterol total pada kelompok perlakuan lebih tinggi disebabkan asam palmitat (SFA) meningkatkan kadar kolesterol dengan menekan aktifitas reseptor LDL yang serta meningkatkan pembentukan kolesterol LDL plasma. ${ }^{12}$

Terdapat perbedaan peningkatan kadar kolesterol total yang tidak bermakna juga dipengaruhi oleh asam oleat (MUFA) pada minyak sawit. Teorinya adalah penambahan jumlah reseptor LDL pada sel hepar oleh MUFA sehingga terjadi peningkatan laju katabolik kolesterol LDL. ${ }^{13,14}$ Konsumsi asam oleat meningkatkan kadar asam oleat dalam hati, yang merangsang meningkatnya enzim esterifikasi kolesterol yaitu acyl-CoA cholesterol acyltransferase (ACAT) sehingga peningkatan aktivitas ACAT dapat menurunkan kadar kolesterol bebas dalam hati. ${ }^{12}$ Turunnya kadar kolesterol merangsang pemecahan sterol response element binding protein, yang kemudian menstimulasi gen reseptor LDL yang mengenali komponen apoprotein $B$-100 LDL yang berperan menangkap LDL secara endositosis masuk ke dalam sel tersebut sehingga menurunkan kadar kolesterol LDL plasma. ${ }^{13}$

Kadar kolesterol total pada diet tinggi minyak sawit tidak mengalami perbedaan dan peningkatan secara bermakna. Hal ini kemungkinan disebabkan adanya komponen minor minyak sawit, di antaranya vitamin E yaitu tokotrienol dan tokoferol. Tokotrienol mengatur kadar kolesterol plasma melalui penghambatan aktivitas enzim HMG-CoA reductase yang mengatur sintesis kolesterol dalam hati. ${ }^{10} \mathrm{Hal}$ ini sejalan dengan hasil penelitian yang menyatakan bahwa tokotrienol mampu menghambat sintesis kolesterol secara in vivo. ${ }^{5}$

Penelitian yang dilakukan oleh Valastyan S bertujuan untuk mengidentifikasi aktivitas spesifik $\alpha$ tokoferol $(\alpha-\mathrm{TOH})$ dalam meregulasi ekspresi gen-gen yang berkaitan dengan biosintesis kolesterol menunjukkan bahwa selain menghambat reaksi radikal bebas, $\alpha-\mathrm{TOH}$ juga mempengaruhi aktivasi proteolitik faktor transkripsi gen-gen pengkode enzim enzim penting pada jalur biosintesis kolesterol sehingga transkripsi dan translasi dihambat. ${ }^{14}$

Berdasarkan analisis data penelitian terhadap HDL menunjukkan bahwa rerata kadar HDL kelompok perlakuan lebih tinggi daripada kelompok kontrol namun tidak terdapat perbedaan yang bermakna antara 2 kelompok tersebut. Hasil yang didapat pada penelitian ini berbeda dengan hasil penelitian KarajiBani yang menggunakan tikus wistar diberi diet minyak sawit $12 \%$ selama 60 hari menunjukkan bahwa kadar HDL pada kelompok perlakuan diet minyak sawit didapatkan lebih tinggi secara bermakna daripada kelompok kontrol. ${ }^{11}$ Hasil penelitian ini sejalan dengan yang disimpulkan Mukherjee bahwa minyak sawit merangsang sintesis kolesterol HDL. ${ }^{5}$

Terdapat perbedaan yang tidak bermakna pada penelitian ini kemungkinan karena kandungan komponen minyak sawit. Berdasarkan analisis secara fitokimia kandungan minyak sawit terdiri dari antioksidan tannins, flavoniods and cyanogenic glycosides, saponin dan $\beta$-carotene. ${ }^{15}$ Penelitian sebelumnya oleh Brown menunjukkan bahwa antioksidan akan meningkatkan kadar HDL dengan 
cara meningkatkan mRNA Apo A1 hati yang berperan untuk menginisiasi sintesis Apo $A 1 .^{16}$ Apo A1 merupakan komponen utama HDL. ${ }^{17}$

Hasil analisis data penelitian didapatkan bahwa rerata rasio kolesterol total/HDL kelompok perlakuan lebih tinggi daripada kelompok kontrol namun tidak terdapat perbedaan yang bermakna antara 2 kelompok tersebut $(p>0.05)$.

Rasio kolesterol total/ HDL atau disebut juga Cardiac Risk Ratio adalah indikator kejadian aterogenesis. $^{18}$ American Heart Association merekomendasikan nilai rasio kolesterol total/ HDL sebaiknya di bawah 5:1 dengan nilai rasio optimal 3.5:1. ${ }^{1}$

Terdapat pergeseran paradigma untuk mempertimbangkan pentingnya perbedaan dalam penyerapan asam lemak dan 2-MAG yang dihasilkan dari aksi enzim pencernaan pada TAG dan bukan hanya komposisi asam lemak keseluruhan lemak. ${ }^{18}$ Minyak sawit dianggap netral karena minyak tidak menaikkan risiko PJK akibat dari asam palmitat yang berada pada posisi sn-1 dan sn-3. ${ }^{20}$ Dengan posisi demikian, asam palmitat yang bersifat aterogenik ini tidak akan diserap sehingga tidak lagi bersifat aterogenik. $^{19,20}$ Efek minyak sawit pada lipid darah lebih seperti MUFA daripada SFA. Hal ini disebabkan 87\% MUFA minyak sawit berada pada posisi sn-2 yang memungkinkan asam lemak oleat mudah diserap. $^{20}$

\section{KESIMPULAN}

Kadar kolesterol total, HDL maupun rasio kolesterol total/HDL pada kelompok kontrol dan kelompok diet tinggi minyak sawit tidak terdapat perbedaan secara bermakna.

\section{UCAPAN TERIMA KASIH}

Ucapan terima kasih kepada Prof. Dr. dr. Ellyza Nasrul, Sp.PK(K) dan dr. Susila Sastri, M.Biomed, yang telah banyak memberikan bimbingan, bantuan dan motivasi dalam penelitian ini.

\section{DAFTAR PUSTAKA}

1. American Heart Association. What Your Cholesterol Levels Mean. 2012; http://www.heart.org. Diakses 6 Maret 2013.

2. Roger VL. Heart Disease and Stroke Statistics2012 Update . American Heart Association.2012; http://circ.ahajournals.org. Diakses pada 25 November 2012

3. World Health Organization, Noncommunicable Disease Country Profiles, Country Statistics Indonesia. 2011; 1.

4. Dinas Kesehatan Kota Padang. Profil Kesehatan Kota Padang Tahun 2011. Dinkes Kota Padang. 2012; 15-6.

5. Mukherjee, Sutapa, Analava M. Health Effect of Palm Oil. J Hum Ecol 26. 2009;(3): 197-203.

6. Mann J. Gizi Kesehatan Masyarakat. Jakarta : EGC, 2004; hal 391-405.

7. Badan Pusat Statistik. Rata-rata Konsumsi Kalori (KKal) per Kapita Sehari Menurut Kelompok Makanan 1999, 2002-2011. 2011; http://www.bps.go.id. Diakses 11 Desember 2012.

8. McNamara DJ. Review Palm Oil and Health: A Case of Manipulated Perception and Misuse of Science. Journal of the American College of Nutrition. 2010; 29(3): 240S-4S.

9. French MA, Sundram K, Clandinin MT. Cholesterolaemic effects of palmitic acid in relation to other dietary fatty acids. Asia Pac J Clin Nutr. 2002; 11: S401-7.

10. Sundram K, Sambanthamurthi R, Tan YA. Review Article Palm Fruit Chemistry and Nutrition. Asia Pacific J Clin Nutr. 2003; 12(3): 355-62.

11. Karaji- Bani M, Montazeri F, Hashemi F. Effect of Palm Oil on Serum Lipid Profile in Rats. Pakistan Journal of Nutrition. 2006; 5(3): 234-6.

12. Fernandez ML, Kristy L. Mechanisms by which Dietary Fatty Acids Modulate Plasma Lipids. The Journal of Nutrition. 2005: 2075-8.

13. Niazi SH, Mirmiran P, Azizi F. Nutritional Management of Disturbances in Lipoprotein Concentrations. InTech. 2012; 303-36.

14. Valastyan S, Thakur V, Johnson A, Kumar K, Manor D. Novel Transcriptional Activities of Vitamin E: Inhibition of Cholesterol Biosynthesis. Biochemistry. 2008; 4: 744-52. 
15. Ibegbulem CO, Chikezie PC. Serum Lipid Profile of Rats (Rattus norvegicus) Fed With Palm Oil and Palm Kernel Oil-containing Diets. Asian Journal of Biochemistry. 2012; 7: 46-53.

16. Brown $B G$, Zhao XQ, Chait $A$, Fisher LD, Cheung MC, Morse JS et al., Simvastatin and niacin, antioxidant vitamins or the combination for the prevention of coronary disease. $\mathrm{N}$ Engl J Med. 2001; 345 (22): 1583-92.

17. Supriyanto. Pengaruh Pemberien Ekstrak Kedelai terhadap Kadar Kolesterol Total, LDL, HDL dan Rasio kolesterol LDL/HDL Darah Tikus Putih Jantan yang Mengalami Hiperkolesterolemia. [Thesis]. 2004. Program Pasca Sarjana Universitas Airlangga Surabaya.
18. Ikewuchi CC. Hypocholesterolemic Effect of An Aqueous Extract of The Leaves Of Sansevieria Senegambica Baker On Plasma Lipid Profile And Atherogenic Indices of Rats Fed Egg Yolk Supplemented Diet. EXCLI Journal. 2012; 11: 318-27.

19. Silalahi J, Nurbaya S. Komposisi, Distribusi dan Sifat Aterogenik Asam Lemak dalam Minyak Kelapa dan Kelapa Sawit. J Indon Med Assoc. 2011; 61(11): 453-7.

20. Berry SEE. Triacylglycerol Structure and linteresterification of Palmitic and Stearic Acid Rich Fats: An Overview and Implications for Cardiovascular Disease. Nutrition Research Reviews. 2006; 22: 3-17. 